\title{
A LIVRE CIRCULAÇÃO DE PESSOAS NO MERCOSUL E NA UNIÃO EUROPEIA: PERSPECTIVAS E DESAFIOS PARA O FUTURO ${ }^{1}$
}

\author{
Luciane Klein Vieira* \\ Vitória Volcato da Costa**
}

RESUMO: Diante da crise migratória e da globalização, o crescimento do nacionalismo e da xenofobia pode causar impactos na livre circulação de pessoas de blocos econômicos que visam um mercado comum. O MERCOSUL pode ser influenciado por este cenário, o que impõe analisar se estaria caminhando para uma política migratória receptiva, para implementar a livre circulação de pessoas ou para o fechamento de fronteiras. Ademais, é relevante o exame do que tem ocorrido na União Europeia, sistema de integração mais exitoso atualmente. Uma análise comparativa entre ambos pode identificar quais as perspectivas e desafios para o futuro.

Palavras-chave: MERCOSUL; União Europeia; Livre circulação de pessoas; Política migratória; Xenofobia.

\section{THE FREE MOVEMENT OF PEOPLE IN MERCOSUR AND IN EUROPEAN UNION: PERSPECTIVES AND CHALLENGES FOR THE FUTURE}

\begin{abstract}
In the face of migration crisis and globalization, the growth of nationalism and xenophobia can cause impacts on the free movement of people of integration systems that aims a common market. The MERCOSUR can be influenced by this scenario, which demands analyze if it is inclining to implement a receptive migration policy, a free movement of people or a borders closing. In addition, it is relevant the examination of what is current happening in European Union, most successful integration system in the world. A comparative analysis between both can identify the perspectives and challenges for the future.
\end{abstract}

Keywords: MERCOSUR; European Union; Free movement of people; Migration policy; Xenophobia.

\footnotetext{
${ }^{1}$ O presente trabalho foi realizado com apoio da Coordenação de Aperfeiçoamento de Pessoal Nível Superior Brasil (CAPES) - Código de Financiamento 001.

* Professora pesquisadora do Programa de Pós-Graduação em Direito da Universidade do Vale do Rio dos Sinos (UNISINOS); Doutora em Direito Internacional pela Universidad de Buenos Aires (UBA); Mestre em Direito Internacional Privado pela UBA; Mestre em Direito da Integração Econômica pela Universidad del Salvador e Université Paris 1 - Pantheón - Sorbonne. Endereço postal: Rua Quintino Bocaiúva, n. ${ }^{\circ}$ 83, Sapiranga/RS - CEP 93800-118. Endereço eletrônico: lucianekleinvieira@yahoo.com.br.

${ }^{* *}$ Mestranda em Direito pela Universidade do Vale do Rio dos Sinos (UNISINOS) - Bolsista CAPES/PROEX; Bacharel em Direito pela Pontifícia Universidade Católica do Rio Grande do Sul (PUCRS); Advogada. Endereço postal: Rua Leopoldo Bier, n. ${ }^{\circ}$ 662, Porto Alegre/RS - CEP 90620-100. Endereço eletrônico: vitoria.volcato@gmail.com.
} 


\section{INTRODUÇÃO}

A sociedade internacional, marcada pelas características da globalização e da interconexão, tem enfrentado a maior crise migratória já vista. Neste cenário, curioso é analisar como sistemas de integração econômica que visam à constituição de um mercado comum efetivo lidam com a questão da livre circulação de pessoas.

Tudo indica que a plena regulamentação e implementação de uma livre circulação de pessoas é benéfica tanto para o processo de integração, quanto para os países que dele fazem parte, bem como para os nacionais destes Estados. Porém, o crescimento do nacionalismo e da xenofobia podem trazer um retrocesso a esta livre circulação nos diferentes processos de integração, tomando de exemplo o que tem ocorrido na União Europeia (UE).

A partir disso, importante é investigar para qual direção o Mercado Comum do Sul (MERCOSUL) está caminhando, se para um aprofundamento da livre circulação de pessoas, para uma política migratória receptiva com imigrantes de terceiros Estados ou para o fechamento das fronteiras. Logo, partindo do contexto supra mencionado, esta pesquisa procura responder às seguintes questões: quais são as perspectivas e desafios do MERCOSUL frente a um cenário marcado, de um lado pela maior crise migratória já vista e pelo incremento da globalização, e de outro pelo crescimento do nacionalismo e da xenofobia? Está o MERCOSUL caminhando na contramão ou na direção das medidas e políticas adotadas pela UE? Que medidas a UE vem tomando na atualidade, a fim de lidar com a crise migratória?

A fim de compreender tais questões, a primeira parte deste escrito irá realizar uma breve contextualização do cenário atual, abordando a crise migratória, o tema da livre circulação de pessoas e da política migratória na UE, o crescimento do nacionalismo e da xenofobia nos Estados Membros e o que isso tem gerado na livre circulação de pessoas no bloco europeu.

$\mathrm{Na}$ segunda parte do presente artigo será analisado o que já foi feito em termos de livre circulação de pessoas e de política migratória no MERCOSUL, traçando um histórico comparativo ao da UE. Por fim, tentar-se-á identificar qual a agenda do bloco sul-americano neste tema para os próximos anos, a fim de avaliar para qual direção o MERCOSUL está caminhando, se na contramão ou na mesma direção da UE. 
Por fim, cabe referir que para a construção do texto que se apresenta, utilizar-se-á o método normativo-descritivo.

\section{OS IMPACTOS ATUAIS DA CRISE MIGRATÓRIA NA LIVRE CIRCULAÇÃO DE PESSOAS NA UNIÃO EUROPEIA}

Desde a Primavera Árabe houve um expressivo aumento nos fluxos migratórios e nas solicitações de refúgio, por conta dos conflitos e guerras civis que eclodiram a partir desta onda de protestos e movimentos no Oriente Médio e norte da África entre 2010 e 2012 (LANTOINE, 2013, p. 1). Segundo o Relatório Tendências Globais do Alto Comissariado das Nações Unidas para Refugiados (ACNUR), em 2017 o número de migrantes forçados chegou a 68,5 milhões, aumentando pelo sexto ano consecutivo, o que representa a maior crise migratória da história.

A maioria dos refugiados vem atualmente dos seguintes países: Síria, Afeganistão, Sudão do Sul, Myanmar e Somália. O maior número de pedidos de asilo e refúgio na Europa foi entre 2015 e 2016 (ACNUR, 2018, p. 7), porém, os Estados Membros da UE não estão entre os países que mais acolhem.

Em 2015, os cinco países que mais concederam asilo e refúgio ${ }^{2}$ foram: Turquia, Paquistão, Líbano, Irã e Etiópia (ACNUR, 2016, p. 3). Em 2016, os países antes apontados continuaram sendo os que mais concederam a proteção referida, contando somente com a inserção de um novo ator internacional: Uganda (ACNUR, 2017, p. 3). No ano de 2017, os países referidos, com a exclusão da Etiópia, continuaram no topo da lista de Estados que mais concedem asilo e refúgio. Como se pode observar, nenhum Estado Membro da UE insere-se entre os países que mais acolheram imigrantes e refugiados. Ademais, dos 68,5 milhões de migrantes forçados, 40 milhões são deslocados internos. (ACNUR, 2018, p. 2-3).

Isso porque no momento em que a crise migratória começou a dar seus sinais, os Estados Membros da UE implementaram uma rígida política migratória de fechamento de

\footnotetext{
${ }^{2}$ Há uma prática regional que foi regulamentada na América Latina, a qual diferencia asilo e refúgio. Neste sentido, o asilo: surgiu do costume internacional; consiste em ceder proteção para um indivíduo que esteja sofrendo perseguição por razões políticas; constitui exercício de um ato soberano do Estado, que tem poder discricionário para concedê-lo ou não. Já o refúgio: faz parte do sistema internacional de proteção da ONU, através do ACNUR; para ser refugiado deve se enquadrar no conceito da Convenção para o Estatuto dos Refugiados de 1951 e do Protocolo adicional de 1967; uma vez enquadrada neste conceito, há uma série de exigências referentes à proteção dessa pessoa, que devem ser respeitadas pelos Estados e não fazem parte do poder discricionário destes. Porém, somente na América Latina asilo e refúgio são institutos diferentes, nos demais países são utilizados como sinônimos.
} 
fronteiras. Desde então, o nacionalismo e a xenofobia têm crescido cada vez mais na Europa, fazendo com que não somente a política migratória seja prejudicial para imigrantes extra comunitários, mas também apresentando impactos negativos na liberdade de circulação dos cidadãos europeus dentro do território integrado.

\subsection{A liberdade de circulação dos cidadãos europeus e a política migratória da União Europeia para imigrantes extra comunitários}

A primeira vez que o tema da livre circulação de pessoas surgiu na Europa, foi a partir do Acordo de Schengen, celebrado em 1985. Apesar de não ter sido criado no âmbito do direito comunitário europeu, o qual na época era constituído pelo acervo legal referente às três comunidades europeias - Comunidade Europeia do Carvão e do Aço (CECA), Comunidade Econômica Europeia (CEE) e Comunidade Europeia da Energia Atômica (EURATOM) -, o Acordo de Schengen foi assinado por países que faziam parte do sistema comunitário. (BATISTA, 1998, p. 136 e 156).

Neste sentido, destaca-se a assinatura do Acordo referido pela Alemanha, França, Bélgica, Países Baixes e Luxemburgo (BATISTA, 1998, p. 156). Não obstante, atualmente, o tratado já conta com 22 dos 28 Estados Membros da UE, mais 4 países que não fazem parte do sistema comunitário (EUR-LEX, Schengen). O objetivo em comum que levou estes países à criação do Acordo, foi o de estabelecer uma livre circulação de pessoas, através da eliminação das fronteiras internas, bem como a intenção de lidar com problemas semelhantes de migração e segurança (BATISTA, 1998, p. 156).

Adicionalmente, em 1986, foi firmado o Ato Único Europeu (AUE), que unificou as três comunidades europeias, estabelecendo o objetivo de formar um mercado comum europeu. Logo, para atingir este objetivo, foram previstas medidas de implementação de uma livre circulação de pessoas, através da supressão das fronteiras internas. (BATISTA, 1998, 136 e 158).

Já em 1992, na Europa foi estabelecido o Tratado de Maastricht ou Tratado da União Europeia (TUE), o qual cria a União Europeia como sucessora da Comunidade Econômica Europeia e estabelece o objetivo de formar uma união econômica e monetária. Diante do aprofundamento da proposta de integração econômica trazida pelo tratado em comento, tornase ainda mais necessária a implementação da livre circulação de pessoas e, para isso, o TUE 
institui a cidadania europeia. A partir de então, aos cidadãos europeus é concedida a liberdade de circulação dentro do território comunitário, bem como uma série de direitos e garantias, como direitos políticos e acesso à justiça comunitária. (BATISTA, 1998, p. 138-142).

Mas ao serem traçadas as linhas de ação para implementar uma livre circulação de pessoas, ao mesmo tempo em que se adota a restrição dos controles fronteiriços para cidadãos dos Estados Membros, também se determina que estes tomem medidas de segurança para coibir a "imigração ilegal” em relação a nacionais de terceiros Estados (BATISTA, 1998, p. 157). A partir de então, de um lado houve forte cooperação entre os serviços policiais e judiciais dos Estados Membros, a fim de eliminar as fronteiras internas e, de outro lado, criouse uma burocracia extrema, através da exigência de rígidos requisitos para concessão de visto e circulação temporária a imigrantes extra comunitários (SILVA, AMARAL, 2013, p. 239240).

A política migratória para imigrantes de terceiros Estados é tratada na UE dentro dos setores da Política Externa e de Segurança Comum (PESC) e da Cooperação em Justiça e Assuntos do Interior (CJAI), os quais sempre estiveram inseridos no pilar intergovernamental do bloco europeu (SILVA, AMARAL, 2013, p. 238). O fato de a política migratória estar inserida no mesmo setor que trata de questões de segurança e terrorismo, já demonstra a maneira problemática pela qual a UE sempre lidou com o tema. Ademais, permitir que os Estados Membros deem vazão a seus próprios interesses nacionais, sobre os interesses comunitários, por conta do caráter intergovernamental dado ao tema, fragiliza a supranacionalidade da UE e pode acabar prejudicando a livre circulação de pessoas.

Apesar de a PESC ter sido "comunitarizada" na última reforma aos tratados constitutivos, introduzida pelo Tratado de Lisboa (realizada em 2007 e com vigência desde 2009), esta somente define alguns elementos gerais acerca da ação da UE para tratar as migrações extra comunitárias, não havendo uma política migratória europeia comum. A UE, portanto, se limita a estabelecer diretrizes gerais no tema, a serem inseridas na legislação nacional de cada Estado membro, ficando todo o resto a cargo destes. (SILVA, AMARAL, 2013, p. 237).

Deste modo, a política migratória europeia é guiada por três eixos, conforme Joaquín Arango (2005): o controle dos fluxos de população, a integração social de migrantes e a cooperação para o desenvolvimento. Com relação ao controle de fluxos de população, este ocorre tanto na origem como no destino dos fluxos migratórios. Em relação à origem, os 
Estados Membros estabelecem critérios de seleção para aqueles migrantes desejados em seu território, através de critérios de concessão de vistos, abrindo sistemas de cotas para trabalhadores, firmando acordos bilaterais e multilaterais com países de origem, etc. Já no destino, se dá através do controle policial nas zonas transfronteiriças. (SILVA, AMARAL, 2013, p. 241-245).

Em relação ao segundo eixo da política migratória - a integração dos imigrantes -, a normativa da UE busca estabelecer que a integração seja bidirecional, ou seja, que tanto ocorra a inserção do imigrante na cultura europeia, como também que a sociedade europeia aprenda sobre essa cultura estrangeira e a considere. No entanto, os Estados Membros estabelecem políticas nacionais que visam impor ao imigrante a cultura e religião europeias, somada às identidades nacionais, sem considerar a aprendizagem da cultura estrangeira e os benefícios que esta pode trazer. (SILVA, AMARAL, 2013, p. 246-248). Ainda, as políticas de integração são voltadas somente àqueles que tenham residência legal, sejam potenciais migrantes a possuir residência legal ou tenham direito a refúgio e outras formas de proteção internacionais reconhecidas pela UE (JUAN, 2016, p. 103), excluindo-se grande parte da população migrante.

A primeira iniciativa que pode ser destacada em relação a uma política migratória da UE, foi o Tratado de Amsterdã, firmado em 1997, que estabeleceu programas quinquenais para executar essa ação. Desde então foram criados o Programa de Tampere (1994 a 2004), o Programa de Haia (2004 a 2009), e o Programa de Estocolmo (2010 a 2014). Todos os programas trataram a questão migratória como um problema para a UE, estabelecendo uma gestão para as migrações em dois pilares, de modo a garantir a liberdade de circulação para cidadãos europeus e ao mesmo tempo adotar medidas de segurança para os imigrantes extra comunitários. (SILVA, AMARAL, 2013, p. 237-239).

Mas o instrumento normativo da UE mais importante no tema das migrações foi o Pacto Europeu sobre Imigração e Asilo, firmado em 2008. Este possui mecanismos de execução, os quais foram o Programa de Haia e posteriormente o Programa de Estocolmo, sempre visando o controle das migrações e a luta contra a clandestinidade (SILVA, AMARAL, 2013, p. 237).

Como se pode observar, o enfoque dado às migrações pela UE, portanto, sempre se deu a partir de uma lógica xenófoba, de proteção das fronteiras externas contra os imigrantes extra comunitários, e, neste sentido, desenvolveu-se um sentimento de intolerância com o 
outro, sobretudo, com o outro "não-europeu". Ainda, o fato de o tema ser tratado dessa forma até o momento atual, ou seja, mesmo após reforma do Tratado de Lisboa, de maneira a deixar a cargo dos Estados Membros a maior parte das questões referentes à política migratória, acaba fragilizando o poder da UE, abrindo espaço para ameaças à livre circulação de pessoas no território europeu.

\subsection{Contexto atual na União Europeia: as consequências do nacionalismo e da xenofobia}

Como visto, o tema da política migratória na UE historicamente apresenta uma lógica de abertura das fronteiras internas para os cidadãos europeus e de fechamento das fronteiras externas para imigrantes de terceiros Estados. Então, a partir do aumento nos fluxos migratórios nos últimos anos, anteriormente contextualizado, houve um crescimento do nacionalismo e da xenofobia na Europa, fazendo com que não somente a política migratória para imigrantes extra comunitários se tornasse mais rígida, como também a própria liberdade de circulação dos cidadãos europeus se veja ameaçada.

Logo após a reforma do Tratado de Lisboa, foi criada a Diretiva 2008/115 do Parlamento e do Conselho, que ficou conhecida como Diretiva de Retorno, publicada em 2008 e ratificada em 2010. A Diretiva foi criada com o objetivo de fazer retornar ao país de origem todo imigrante que esteja ilegalmente no território europeu ou que não cumpra com os requisitos para a concessão de refúgio. (PEREIRA, 2014, p. 84-86). Porém, é importante observar que o termo ilegal, nas palavras de Gustavo Pereira (2014, p. 85), "sugere uma subcategoria de ser humano que, pelo simples fato de ter deixado o seu país de origem, em grande parte por necessidades sociais e econômicas, é considerado criminoso".

Ainda, a Diretiva também permite que mesmo aquele imigrante que ingressou de forma regular ou teve reconhecido seu status de refugiado, pode perder estes direitos a qualquer momento, de acordo com os critérios de cada Estado Membro. Logo, milhares de pessoas, entre elas crianças, já foram retornadas e até mesmo aprisionadas enquanto se dá o processo de retorno. (PEREIRA, 2014, p. 84-86).

Por fim, verifica-se que tudo isso impacta na liberdade de circulação dos cidadãos europeus. O primeiro sinal desse impacto deu-se, em 2012, quando Alemanha e França suspenderam temporariamente o Acordo de Schengen, sem consulta prévia ao Parlamento 
Europeu e ao Conselho Europeu, com o objetivo de evitar a imigração irregular. (SILVA, AMARAL, 2013, p. 243-244).

Já em 2013, quando os fluxos migratórios se intensificaram ainda mais, diante das consequências advindas da Primavera Árabe, foram inseridos dispositivos no Acordo de Schengen que permitem a suspensão temporária e o restabelecimento do controle das fronteiras internas pelos Estados Membros, em caso de "séria ameaça à segurança interna" (COMISSÃO EUROPEIA, 2018), contudo, de maneira muito genérica. A partir disso, verifica-se que somente até a metade do ano de 2018, entre aqueles Estados que suspenderam e já retornaram e aqueles em que ainda se encontra suspenso o Acordo, houve a retomada do controle das fronteiras internas por 15 países europeus (COMISSÃO EUROPEIA, 2018).

Seguindo nesta mesma lógica, em 29 de junho de 2018, na reunião do Conselho Europeu, todos os Estados Membros da UE firmaram um acordo para a criação de "centros de triagem", para os quais serão enviados os imigrantes que chegam no território europeu, a fim de nestes locais separar-se quem tem direito a refúgio e quem é migrante econômico, com o objetivo de devolver estes últimos a seus países de origem. (EL PAÍS, 2018).

O referido acordo também faz com que sejam eliminadas as cotas obrigatórias, as quais exigiam que os Estados Membros tinham de receber certa porcentagem de imigrantes em seu território, sob o princípio da solidariedade entre os integrantes do sistema comunitário. Neste novo acordo, porém, somente aqueles países que voluntariamente desejarem, poderão construir os centros de triagem em seu território. (EL PAÍS, 2018). Isso beneficia aqueles Estados Membros que se recusam a receber imigrantes e refugiados, bem como fragiliza ainda mais a liberdade de circulação dos cidadãos europeus, pois enquanto alguns países recebem certo número de imigrantes, ainda que pequeno, outros se negam a receber qualquer estrangeiro, o que estimula o fechamento das fronteiras internas.

Outro ponto do acordo que simboliza que a UE ainda segue com uma política de fechamento de fronteiras, é que este estabelece a criação de plataformas de desembarque de imigrantes fora do território europeu, a serem instauradas em países do norte da África, como Líbia, a fim de se evitar a travessia para os países europeus (EL PAÍS, 2018).

Tudo isso demonstra que a UE tem caminhado cada vez mais para o fechamento de suas fronteiras externas, criando uma espécie de "Europa Fortaleza" (WERMUTH, 2014, p. 124). Mas também vem seguindo uma direção na qual os Estados Membros também podem 
cada vez mais fecharem suas fronteiras internas, prejudicando a livre circulação de pessoas no bloco europeu. Neste sentido, diz Pablo Pérez Espigares (2018, p. 174):

\begin{abstract}
Desmintiendo con esas prácticas sus pretensiones civilizatorias en cuanto a derechos humanos, democracia y política internacional según un principio de justicia, la Unión Europea se diluye como espacio de ciudadanía común. Éste, con el deterioro del modelo social europeo por el predominio de la ideología neoliberal, queda hecho añicos con esa injustificada e injusta política de exclusión.
\end{abstract}

Tais políticas referentes à migração "estão sendo construídas de cima para baixo" e funcionam como políticas repressivas e excludentes, baseadas em práticas que acabam por priorizar o controle das fronteiras, em detrimento da própria ideia de integração e do respeito aos direitos humanos dos imigrantes (WERMUTH, 2014, p. 125).

\title{
3. A LiVRe CirculaÇÃo de PeSSOAS E A POLÍtica Migratória NO MERCOSUL
}

$\mathrm{O}$ art. $1^{\circ}$ do Tratado de Assunção, tratado constitutivo do MERCOSUL, já estabelece o objetivo de formar um mercado comum, o que implica na "livre circulação de bens, serviços e fatores produtivos entre os países" (1991). Apesar deste bloco sul americano ainda não ter alcançado a etapa econômica referida, sendo classificado atualmente como uma união aduaneira imperfeita, é possível destacar uma série de avanços e esforços na direção de uma maior liberdade de circulação para os nacionais dos Estados Parte, tendo em vista o objetivo acima citado.

Em relação à política migratória, seja para migrantes dos Estados Parte ou de terceiros Estados, apesar de o MERCOSUL não contar com órgãos supranacionais e carecer de uma política migratória comum, muitos avanços vem sendo realizados no âmbito da cooperação intergovernamental no tema (NICOLAO, 2015, p. 3).

Cabe destacar que os países do MERCOSUL formam uma região que historicamente possui alta circulação de pessoas, seja por razões econômicas, exílios políticos ou turismo/intercâmbio cultural, e, por conta disso, foi necessário estabelecer mecanismos para combater certas questões, como, por exemplo, a de imigrantes, que, por se encontrarem em condições migratórias irregulares, passam a se sujeitar a trabalhos informais e extremamente precários (GARCÍA, 2012, p. 23-27), nos quais há clara violação de direitos humanos. 
Há muitos desafios ainda para se lidar nesta temática, assim como aqueles descritos na primeira parte deste artigo, o que impõe analisar para qual direção o MERCOSUL está caminhando, se para um aprofundamento da livre circulação de pessoas, para uma política migratória receptiva ou para o fechamento das fronteiras nacionais.

\subsection{A história da migração no MERCOSUL}

É possível estabelecer uma divisão característica de como o tema da migração e da livre circulação de pessoas foi abordado em dois momentos distintos no MERCOSUL. De um lado, na década de 90, a abordagem do tema foi com ênfase na segurança dos países. De outro lado, a partir dos anos 2000, a mudança de governos com perfil mais progressista nos Estados Parte impôs uma abordagem mais focada no desenvolvimento econômico-social e trouxe ao bloco assuntos que antes estavam marginalizados, assim como a questão migratória, resultando em avanços significativos em relação à livre circulação de pessoas e à cidadania do MERCOSUL. (NICOLAO, 2015, p. 7).

Assim que o Tratado de Assunção entrou em vigor foram criados dois subgrupos de trabalho para lidar com o tema da migração: (i.) SGT 2 - Assuntos Aduaneiros: controle migratório e facilitação fronteiriça, coordenação administrativa, determinação comum dos documentos necessários, compatibilização normativa migratória, controle de turistas de terceiros países e análise da possibilidade de criação de um documento único para nacionais dos Estados Parte; (ii.) SGT 11 - Relações de trabalho, emprego e seguridade social: comparação de estatísticas e legislações trabalhistas dos Estados Parte, bem como dos fluxos migratórios com motivação de trabalho entre esses países (GARCÍA, 2012, p. 27).

A partir da reforma do Protocolo de Ouro Preto, em 1994, o tema das migrações deixou de ser tratado pelos referidos SGT's e, em 1997, é criada uma Comissão sobre Migrações Trabalhistas, que fez surgir um projeto para pesquisar sobre trabalhadores transfronteiriços. Essa medida resultou no acordo de 1999 chamado "Entendimento sobre migração transfronteiriça nos Estados Parte do MERCOSUL, Bolívia e Chile” e em 2000 na “Regulamentação do regime de migração transfronteiriça" (GARCÍA, 2012, p. 28).

Em relação ao refúgio, foi firmada, em 2000, pelo MERCOSUL, a Declaração do Rio de Janeiro sobre a Instituição do Refúgio. Nesta Declaração, os Estados Parte reconheceram o direito universal de solicitar refúgio previsto na Declaração Universal de 
Direitos Humanos (DUDH), bem como se comprometeram a garantir a proteção dos refugiados, nos termos da Convenção relativa ao Estatuto dos Refugiados de 1951 e do Protocolo relativo ao Estatuto dos Refugiados de 1967, através de cooperação com o ACNUR, e estabeleceram que cada Estado Parte deve possuir uma norma jurídica específica sobre refúgio, a fim de harmonizar as legislações nacionais acerca do tema (CANEPA, 2015, p. 167).

Já em 2001 foi firmada a "Declaração sobre tráfico de pessoas e tráfico ilícito de migrantes", o que mais tarde levou ao "Acordo sobre Tráfico ilícito de migrantes no MERCOSUL", em 2004 (GARCÍA, 2012, p. 28-29).

O principal passo que o MERCOSUL deu em direção à livre circulação de pessoas foi a adoção dos acordos de residência, ambos firmados em 2002 e com vigência a partir de 2009: o Acordo de Residência para Nacionais dos Estados Parte do MERCOSUL e o Acordo de Residência para Nacionais dos Estados Parte do MERCOSUL, Bolívia e Chile, sendo que neste último aderiram também Equador e Peru, em $2011^{3}$ (SCOTTI, 2018, p. 98). Estes acordos surgiram em um contexto no qual os países do bloco estavam passando por problemas semelhantes, bem como por mudanças nos governos, os quais passaram a compartilhar as mesmas ideologias socioeconômicas, como dito antes.

Os principais dilemas que envolviam o tema e que impulsionaram a realização dos acordos foram, de acordo com Ludmila Culpi (2017, p. 14):

[...] i) a ausência de estatísticas adequadas sobre os fluxos migratórios em suas fronteiras; ii) a necessidade de promover a regularização dos imigrantes ilegais residentes nos territórios nacionais dos Estados Partes do bloco; e iii) a urgência em prevenir e evitar a exploração do trabalho dos imigrantes e o tráfico internacional de pessoas.

Logo, os acordos expressam o desejo dos Estados de implementar uma política de livre circulação de pessoas (regulando o processo de obtenção de residência permanente e temporária), buscar uma solução para a situação migratória de cidadãos dos Estados Parte (concessão de residência permanente ou temporária para aqueles que já se encontram no país receptor) e combater o tráfico de pessoas (GARCÍA, 2012, p. 91-93).

A fim de atingir os dois primeiros objetivos, os acordos concedem o direito de residência legal para os cidadãos que queiram residir em um dos Estados Parte, mediante a

\footnotetext{
3 Ambos os acordos estão atualmente vigentes em todos os Estados signatários. (Disponível em:
} <http://www.mre.gov.py/tratados/public_web/ConsultaMercosur.aspx>. Acesso em: 18 jul. 2018) 
comprovação de que é nacional de um destes países, através de seu documento de identificação (SCOTTI, 2018, p. 98). Do mesmo modo, aqueles que já se encontram no país receptor, podem solicitar a residência naquele Estado Parte, sem precisar retornar ao seu de origem, bem como sem interessar a categoria migratória pela qual ingressou naquele território, e sem aplicação de multas para aqueles que estão em situação irregular (NICOLAO, 2015, p. 8). Com a nacionalidade, além de outros requisitos, é concedida a residência temporária por dois anos, sendo possível transformá-la em permanente mediante solicitação e preenchimento de requisitos, tais como apresentar certidão de antecedentes penais e pagamento de taxa (GARCÍA, 2012, p. 92).

Diante disso, verifica-se que os acordos de residência inovaram no sentido de que não atribuíram aos requisitos autorizadores da residência critérios voltados para a atividade a ser desempenhada por essas pessoas - relativos ao trabalho - mas sim, focados somente na nacionalidade do solicitante. (NICOLAO, 2015, p. 8). Porém, o processo de implementação dos acordos se deu de maneira lenta, bem como enfrentou e enfrenta até hoje alguns problemas, dos quais se podem destacar os seguintes, de acordo com Julieta Nicolao (2015, p. 9):

\begin{abstract}
a) que no todos los países se encuentran aplicando los términos del acuerdo en relación a la totalidad de los signatarios (algunos Estados como Brasil lo sustentan en el principio de reciprocidad, otros como Chile aún no incluyen a los Estados asociados que han adherido al mismo); b) que los procedimientos de internalización o la jerarquía normativa con la que se lo implementa a nivel nacional difiere entre los países; c) que en algunos casos, como ha sucedido en Paraguay, se registra falta de información a los destinatarios sobre los derechos que reconoce el acuerdo, reticencia de los efectores de los organismos migratorios que deben adecuar procesos administrativos, sumado a excesivos tiempos para la resolución de trámites y limitados lugares para su gestión; d) y otros, como ha sucedido en Bolivia, en los que se observa el cobro de excesivas sumas de dinero en carácter de multas diarias o sanciones por permanencias fuera de término (violando las disposiciones del acuerdo); solicitudes de documentación adicional como contratos de alquiler o títulos de propiedad, entre otros requisitos, que sólo recientemente se han ido ajustando.
\end{abstract}

No mesmo ano em que foram construídos os Acordos de residência, em 2002, também foram firmados o Acordo sobre Regularização Migratória Interna de Cidadãos do MERCOSUL e o Acordo sobre Regularização Migratória Interna de Cidadãos do MERCOSUL, Bolívia e Chile, conhecido como Acordo Espelho. Tais tratados visam sanar a questão do requerimento de saída do país, ou seja, aqueles imigrantes que já estão fora do seu país de origem não precisam retornar para pedir sua permanência e, a partir disso, os Estados 
poderão conceder residência temporária ou permanente de acordo com seu direito interno. Porém, ambos os acordos ainda não entraram em vigor, pois o primeiro não foi internalizado pela Argentina, e o segundo não foi internalizado por Argentina e Bolívia (MERCOSUL, 2018). Por conta disso, houve alguns acordos bilaterais sobre regularização migratória, como, por exemplo, o "Acordo, por troca de notas, sobre Regularização Migratória"4 entre Bolívia e Brasil, firmado em 15 de agosto de 2005, o qual previa que os imigrantes de ambos os países que estivessem irregulares no território do outro, independentemente do motivo, pudessem regularizar-se até a data da assinatura do acordo, desde que apresentasse certos requisitos e requeresse em até cento e oitenta dias da data da vigência do tratado. (GARCÍA, 2012, p. 9294).

Paralelamente à criação de todos estes acordos, em virtude da demora em se dar plena vigência, a Argentina resolveu avançar em matéria migratória sozinha, sem esperar os outros países do MERCOSUL, a fim de regularizar os imigrantes de países vizinhos (GARCÍA, 2012, p. 27), criando uma nova Lei de Migrações.

Até a assinatura dos acordos de residência os esforços maiores foram relativos à livre circulação de cidadãos dos Estados Parte do bloco, mas o tema da migração expandiu no MERCOSUL a partir de 2003, quando foi criado o Foro Especializado Migratório (FEM), por iniciativa da delegação Argentina (GARCÍA, 2012, p. 29). Trata-se do órgão do MERCOSUL responsável por tratar integralmente a matéria de migração e que segue atuante até o presente momento, fazendo com que o tema das migrações deixasse de ser tratado no mesmo âmbito das questões de segurança (NICOLAO, 2015, p. 5 e 10).

O FEM funciona no âmbito da Reunião de Ministros do Interior e serve para processos migratórios que vem de dentro e de fora da região. Em suas funções, o FEM realiza estudos de projetos migratórios, confere soluções e propostas na temática, bem como tem adotado medidas em relação à circulação de pessoas e residência legal (CANEPA, 2015, p. 166). As resoluções são adotadas por consenso e levadas à Reunião de Ministros do Interior, para em seguida serem apresentadas ao Conselho do Mercado Comum (CMC) e este incluílas ao direito derivado do MERCOSUL (NICOLAO, 2015, p. 10). Entre os objetivos principais do FEM está o de resolver um dos maiores problemas do bloco, que é o de aplicar efetivamente os compromissos assumidos, bem como harmonizar as legislações nacionais na matéria. (NICOLAO, 2015, p. 10-11).

\footnotetext{
${ }^{4}$ Publicado no Diário Oficial da União (DOU) nº. 179, de 16/09/2005, Seção 1 página 67.
} 
A atuação da Argentina como protagonista no FEM e a criação de sua Lei de Migrações em 2003, considerada uma das legislações mais modernas do mundo, ocorreu por esta ser o maior país receptor de imigrantes da região (NICOLAO, 2015, p. 3; CULPI, 2017, p. 12), em especial de bolivianos e chilenos. De acordo com Lila García (2012, p. 23) "[...] la llegada de nacionales bolivianos a Buenos Aires (Ciudad y GBA) casi se triplicó durante el período 1990-2002 (59.119 personas) en relación a 1980-89 (con un total de 25.543)". Portanto, a Argentina tem interesse em patrocinar um marco regional sobre migração e necessita da cooperação dos demais Estados Parte do MERCOSUL para viabilizar os objetivos de sua política migratória. (CULPI, 2017, p. 12).

A primeira vez que o bloco trouxe um instrumento normativo em relação ao tema das migrações em geral, isto é, abrangendo migrantes de terceiros Estados e não restringindo somente ao instituto do refúgio, foi na Declaração de Santiago sobre Princípios Migratórios de 2004. Nesta Declaração, os Estados Parte comprometem-se em promover o respeito aos direitos humanos das pessoas migrantes de acordo com as convenções internacionais na matéria, bem como promover a proteção internacional dos refugiados nos termos da Convenção de 51 e Protocolo de 67. Ainda, a Declaração reconhece o direito dos Estados referidos de realizar o controle de suas fronteiras, mas sem tratar a irregularidade migratória como algo punível pelo direito penal, ou seja, não permitindo a criminalização da migração. Por fim, também condena práticas de xenofobia, deportações em massa e prisões sem respaldo legal (CANEPA, 2015, p. 166).

Alguns anos depois da promulgação da Lei de Migrações da Argentina, o Uruguai e o Brasil também promulgaram novas leis migratórias, ambas reconhecendo o direito de migrar como um direito humano. O Uruguai promulgou uma nova lei de migração em 2008, Lei n. ${ }^{\circ}$ 18.250/08, tomando como base os mesmos princípios da lei argentina. (NICOLAO, 2015, p. 13). Já em 2017, entrou em vigor no Brasil a nova Lei de Migração, Lei n. ${ }^{\circ}$ 13.445/17, considerada um grande avanço no tema das migrações, especialmente no que tange aos direitos humanos, na qual também houve um processo de transferência da experiência argentina. (CULPI, 2017, p. 19).

Em 2008, foi aprovado o Acordo sobre Documentos de Viagem dos Estados Parte do MERCOSUL e Associados, o qual foi posteriormente ampliado pelo Acordo sobre Documentos de Viagem e Retorno dos Estados Parte do MERCOSUL e Estados Associados, em 2015. A partir disso, foi reconhecido como documento hábil para circular pelos Estados 
signatários outros documentos de identidade dos nacionais ou daqueles que possuem residência regular em algum destes países (SCOTTI, 2018, p. 98). Por exemplo, para aqueles que migram do Brasil para outro Estado Parte, se reconhece como documentos válidos para circular o Registro de Identidade Civil, a Cédula de Identidade expedida por cada Unidade da Federação com validade nacional, a Cédula de Identidade de Estrangeiro ${ }^{5}$ e o Passaporte. Já o documento de retorno concedido pelo Brasil é a Autorização de Retorno. (MERCOSUL, 2015).

Todo o trabalho realizado pelo MERCOSUL até este momento representou uma política de bloco contrária às correntes xenófobas percebidas no resto do mundo (GARCÍA, 2012, p. 28) - em especial como visto na UE. Cabe agora analisar o que tem sido feito recentemente.

\subsection{Agenda atual e futura do bloco}

O segundo passo mais importante depois dos Acordos de residência acerca da livre circulação de pessoas no MERCOSUL é o plano de ação para adotar progressivamente um Estatuto da Cidadania do MERCOSUL, que deve estar plenamente implementado em 2021 data do trigésimo aniversário do Tratado de Assunção -, o qual foi criado a partir da Decisão n. ${ }^{\circ}$ 64/2010 do CMC, durante a presidência pro tempore do Brasil (SCOTTI, 2018, p. 104; NICOLAO, 2015, p. 11). Tal iniciativa é de extrema importância, pois foi depois de ser reconhecida a cidadania europeia no Tratado de Maastricht, assim como visto anteriormente, é que a UE conseguiu avançar na eliminação das fronteiras internas.

O objetivo é que este Estatuto seja ao final instrumentalizado na forma de um protocolo adicional ao Tratado de Assunção, trazendo o conceito de cidadão do MERCOSUL para integrar o direito originário do bloco e, consequentemente, o ordenamento jurídico de todos os Estados Parte. A ideia do referido plano também é estabelecer uma série de benefícios e direitos fundamentais para os cidadãos do MERCOSUL, que estará integrada ao Estatuto. (SCOTTI, 2018, p. 104-105; MERCOSUL, 2010).

O art. $2^{\circ}$ da Decisão n. ${ }^{\circ}$ 64/2010 do CMC diz que o plano terá como base os seguintes objetivos, extraídos dos tratados constitutivos e das normas de direito derivado do bloco:

\footnotetext{
${ }^{5}$ Desde a promulgação da nova Lei de Migração brasileira, Lei n. ${ }^{\circ} 13.445 / 17$, este documento passou a se chamar Carteira de Registro Nacional Migratório.
} 
[...] Implementação de uma política de livre circulação de pessoas na região; lgualdade de direitos e liberdades civis, sociais, culturais e econômicas para os nacionais dos Estados Partes do MERCOSUL; lgualdade de condições para acesso ao trabalho, saúde e educação.

Nesse sentido, o referido plano de ação irá tratar sobre circulação de pessoas, fronteiras, identificação, documentação e cooperação consular, trabalho e emprego, previdência social, educação, transporte, comunicações, defesa do consumidor e direitos políticos (MERCOSUL, 2010). Para tanto, foram estabelecidas uma série de atividades a serem desenvolvidas em cada um dos pontos citados, as quais serão postas em prática através da elaboração de planos de trabalho nas diversas instâncias do bloco, cada uma em sua área de competência (NICOLAO, 2015, p. 11; VIEIRA, 2017, p. 182-184).

A fim de verificar os avanços neste sentido, estabeleceu-se que o alto representante geral do MERCOSUL ${ }^{6}$ iria informá-los nas reuniões ordinárias do CMC (SCOTTI, 2018, p. 105). O que se pode destacar até o presente momento como esforços do bloco no sentido de implementar o plano são as seguintes iniciativas: a criação do Sistema Integrado de Mobilidade do MERCOSUL (SIMERCOSUL), relativo à concessão de bolsas de intercâmbio para pesquisadores da região; a criação da placa comum de identificação veicular do MERCOSUL, a qual ainda não foi implementada em todos os Estados Parte $^{7}$; a revisão do Acordo de Recife, relativo ao controle integrado dos fluxos migratórios nas fronteiras; a revisão da Declaração Sociolaboral do MERCOSUL e o Plano para Facilitar a Circulação de Trabalhadores no MERCOSUL.

Entretanto, a maioria das medidas tomadas a partir do plano foram as de reafirmar novos compromissos, reconhecer a existência de direitos e firmar novos planos de ação mais específicos dentro do âmbito do principal, mas relativamente às ações efetivamente implementadas na prática, não foram verificados avanços significativos (NICOLAO, 2015, p. 12). De fato, o Estatuto da Cidadania tem enfrentado diversos desafios para ser implementado nos últimos anos, o que em grande parte tem relação com a necessidade de fortalecimento institucional e financeiro do bloco, bem como de conferir prioridade para essa agenda, que se

\footnotetext{
${ }^{6} \mathrm{O}$ alto representante geral do MERCOSUL tinha que ser nacional de um dos Estados Parte, bem como ser uma personalidade política destacada e experiente nos temas da integração. Esta pessoa era designada pelo CMC para exercer um mandato de três anos. Porém, através da decisão 06/2017, o CMC eliminou a figura desse representante, assumindo suas funções a Secretaria do MERCOSUL.

${ }^{7}$ No Brasil, a data para implementação da placa comum do MERCOSUL foi adiada, tendo como novo prazo o dia $1^{\circ}$ de setembro de 2018 para veículos novos em processo de transferência de município ou propriedade ou quando houver a necessidade de substituição de placa, e o dia 31 de dezembro de 2023 para os demais casos.
} 
insere no âmbito social do MERCOSUL (PROGRAMA MERCOSUL SOCIAL E SOLIDÁRIO, 2016, p. 23-24).

De outro lado, desde o ano em que foi desenvolvido o plano de ação para o Estatuto do Cidadão, o impacto foi positivo no tratamento doméstico dado pelos Estados Parte aos imigrantes de terceiros Estados, efeito inverso ao do reconhecimento da cidadania europeia, com relação à política migratória da UE. Ainda, o tratamento conferido por países europeus a nacionais do MERCOSUL, em especial pela Diretiva de Retorno - referida na primeira parte deste artigo -, fez com que as leis dos Estados Parte do bloco sul-americano incluíssem melhor tratamento aos imigrantes de terceiros Estados, a partir de um enfoque de direitos humanos (Instituto de Políticas Públicas em Direitos Humanos do MERCOSUL - IPPDH, Organização Internacional para as Migrações - OIM, 2016, p. 30), a exemplo do ocorrido com a nova Lei de Migração do Brasil.

Apesar dos avanços do MERCOSUL na temática migratória e na livre circulação de pessoas, verifica-se que muitos ainda são os desafios. Entre os desafios que acompanham o bloco até o momento atual, que dificultam que seja colocado em prática os objetivos assumidos nas reuniões e normativas do MERCOSUL, está o da falta de vontade política, a carência de uma estrutura institucional, debilidades administrativas, falta de capacitação dos agentes públicos, assimetrias em relação às realidades migratórias de cada Estado Parte, etc. (NICOLAO, 2015, p. 5 e 9).

O importante de se observar é que no momento atual o mundo em geral está sofrendo um movimento voltado a ideologias mais individualistas e que acabam por alimentar sentimentos nacionalistas e/ou xenófobos. É possível observar tal movimento nos países sulamericanos, pois estes se encontram em um cenário de crise econômica e política, ascensão de governos mais conservadores e neoliberais, bem como a situação do fluxo migratório vindo da Venezuela para os demais Estados Parte. Todas essas questões podem influenciar a maneira como o tema das migrações é tratado no bloco, em especial como a agenda social em geral será tratada, sendo possível que o MERCOSUL se reposicione nos próximos anos com foco voltado somente para a economia. (PROGRAMA MERCOSUL SOCIAL E SOLIDÁRIO, 2016, p. 26). 


\section{CONCLUSÃO}

A partir do estudo apresentado, verificou-se que em relação à UE, o tema das migrações tem sito pautado pela lógica da segurança, ou seja, da proteção das fronteiras externas europeias. Com o aumento dos fluxos migratórios nos últimos anos, que gerou a chamada crise migratória, houve um crescimento do nacionalismo e da xenofobia na Europa, fazendo com que os Estados Membros venham adotando cada vez mais medidas de fechamento não só das fronteiras externas, mas também das fronteiras internas, prejudicando a liberdade de circulação dos próprios cidadãos europeus. Analisando, portanto, as atividades recentes tanto da UE quanto de seus Estados Membros, constata-se que a Europa segue cada vez mais inclinada a uma política migratória xenófoba e a prejudicar a livre circulação de pessoas no território integrado.

Em relação ao MERCOSUL, apesar de ainda não ter implementado um mercado comum, não contando com uma efetiva circulação de pessoas, assim como na UE, muitos esforços foram realizados ao longo dos anos. Tanto em termos de livre circulação de pessoas e reconhecimento de uma cidadania comum, quanto em relação à política migratória para imigrantes de terceiros Estados, foram identificados diversos avanços. Entretanto, o MERCOSUL lida com diversos problemas inerentes à sua realidade específica, como a carência de recursos e de fortalecimento institucional, bem como o caráter intergovernamental adotado desde o princípio, diverso da supranacionalidade existente na UE. São, portanto, contextos diferentes.

Entretanto, assim como no início dos anos 2000 os Estados Parte do MERCOSUL passaram por mudanças de governos, com ideologias socioeconômicas semelhantes, no momento atual também vem ocorrendo tais transformações, porém, para ideologias neoliberais. Isso aponta que o bloco sul americano pode seguir um caminho diverso do até então adotado, focando mais na parte econômica e não tanto na agenda social, onde se insere o tema da livre circulação de pessoas. Além disso, verifica-se que nos anos mais recentes, pouco foi feito em relação ao plano de ação para implementar o Estatuto da Cidadania do MERCOSUL.

Diante de tudo isso, é possível constatar que o MERCOSUL até o contexto mais recente seguiu um caminho diverso da UE em relação à política migratória para imigrantes de terceiros Estados. No que tange à livre circulação de pessoas, o bloco europeu já a 
implementou na prática, mas agora caminha para um retrocesso. O bloco sul americano não chegou a implementar esta livre circulação de pessoas, mas apresentou diversos avanços, porém, recentemente, verifica-se a ausência de progressos significativos, havendo a possibilidade de o MERCOSUL aproximar-se do que tem ocorrido na UE. Desta feita, tornase assunto de extrema relevância e urgência a inserção da temática migratória na agenda oficial de ações a serem tomadas pelo CMC, tendo em vista, sobretudo, as necessidades derivadas da migração intra bloco, agravada pela situação dos migrantes venezuelanos.

\section{REFERÊNCIAS}

ACNUR. Global Trends Report = Relatório Tendências Globais. Genebra, 19 jun. 2016. Disponível em: <http://www.unhcr.org/statistics/unhcrstats/576408cd7/unhcr-global-trends2015.html>. Acesso em: 24 jul. 2018.

ACNUR. Global Trends Report = Relatório Tendências Globais. Genebra, 19 jun. 2017. Disponível em: <http://www.unhcr.org/statistics/unhcrstats/5943e8a34/global-trends-forceddisplacement-2016.html>. Acesso em: 24 jul. 2018.

ACNUR. Global Trends Report = Relatório Tendências Globais. Genebra, 19 jun. 2018. Disponível em: <http://www.unhcr.org/5b27be547>. Acesso em: 08 jul. 2018.

BATISTA, Vanessa Oliveira. União Europeia: livre circulação de pessoas e direito de asilo. Belo Horizonte: Del Rey, 1998.

CANEPA, Martin. Los Derechos Humanos en el Mercosur. In: Revista de la Secretaría del Tribunal Permanente de Revisión, Ano 3, n. ${ }^{\circ}$ 6; Agosto 2015; p. 161-177.

COMISSÃO EUROPEIA. Temporary Reintroduction of Border Control. Migration and Home Affairs, 17 July 2018. Disponível em: <https://ec.europa.eu/home-affairs/what-wedo/policies/borders-and-visas/schengen/reintroduction-border-control>. Acesso em: 17 jul. 2018.

CULPI, Ludmila Andrzejewski. Nova Lei de Migrações Brasileira: Inspiração no Modelo da Lei Migratória Argentina? NEPRI, Núcleo de Pesquisa em Relações Internacionais da Universidade Federal do Paraná (UFPR), 2017. Disponível em: $<$ http://www.humanas.ufpr.br/portal/nepri/files/2012/04/Nova-lei-demigra\%C3\%A7\%C3\%B5es-brasileira_Inspira\%C3\%A7\%C3\%A3o-no-modelo-da-leiargentina.pdf>. Acesso em: 11 jul. 2018.

EUR-LEX. Schengen (Acordo e Convenção). Disponível em: <https://eurlex.europa.eu/summary/glossary/schengen_agreement.html?locale=pt $>$. Acesso em: 16 jul. 2018. 
GARCÍA, Lila Emilse. Migración y Derechos Humanos: Implicancias de la Nueva Política Migratoria Argentina. 2012. Dissertação (Mestrado em Relações Internacionais). Facultad de Ciencias Jurídicas y Sociales, Instituto de Relaciones Internacionales, Universidad Nacional de La Plata. La Plata, Argentina. 2012.

IPPDH; OIM. Migración, derechos humanos y política migratória. $1^{\text {a }}$ edição, 2016. Buenos Aires, Argentina. Disponível em: <http://www.ippdh.mercosur.int/serie-migracion-yderechos-humanos/>. Acesso em: 15 jul. 2018.

JUAN, Laura García. La Política de Integración de inmigrantes en el nuevo Fondo de asilo, migración y integración de la Unión Europea. El caso español en el punto de mira. In:

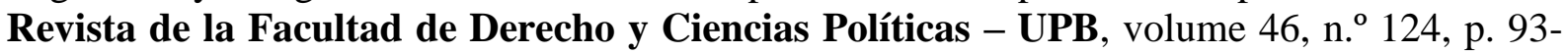
115, junho/2016. Medelín, Colombia. Disponível em: <https://revistas.upb.edu.co/index.php/derecho/article/view/6939>. Acesso em: 13 jul. 2018.

LANTOINE, Alain Montalvão. O Impacto da Primavera Árabe nas Políticas de Migração e Asilo da União Europeia no Mediterrâneo: Mare Nostrum. 2013. Dissertação (Mestrado em Relações Internacionais). Faculdade de Economia, Universidade de Coimbra. Coimbra, Portugal. 2013.

MERCOSUL. Acordo sobre Documentos de Viagem e de Retorno dos Estados Partes do MERCOSUL e Estados Associados. 2015. Disponível em: <http://www.mre.gov.py/tratados/public_web/DetallesTratado.aspx?id=WuM7Y3cTa2u8ayq yIB6pEA\%3d\%3d\&em=lc4aLYHVB0dF+kNrtEvsmZ96BovjLlz0mcrZruYPcn8\%3d>.

Acesso em: 18 jul. 2018.

MERCOSUl. Estatuto da Cidadania do MERCOSUL: Plano de Ação. CMC, Decisão n. ${ }^{\circ}$ 64/2010, 16 dezembro 2010. Disponível em: <http://www.mercosur.int/innovaportal/v/2376/2/innova.front/decisiones-2010>. Acesso em: 14 jul. 2018.

MERCOSUL. Tratados, Protocolos y Acuerdos. 2018. Disponível em: $<$ http://www.mercosur.int/innovaportal/v/5271/2/innova.front/tratados-protocolos-yacuerdos $>$. Acesso em: 18 jul. 2018.

NICOLAO, Julieta. Las Migraciones en la Agenda Del MERCOSUR. El Rol de Argentina en El Foro Especializado Migratorio. Revista Electrónica de Estudios Internacionales, número 29, 2015. Disponível em: <http://www.reei.org/index.php/revista/num29/notas/migraciones-agenda-mercosur-rolargentina-foro-especializado-migratorio>. Acesso em: 10 jul. 2018.

PEREIRA, Gustavo Oliveira de Lima. Direitos Humanos e Hospitalidade. São Paulo: Editora Atlas S.A., 2014.

PÉREZ ESPIGARES, Pablo. Diferencia y exclusión: alergia al otro en el seno de Europa. In: Revista Internacional de Filosofía y Teoría Social - Universidad del Zulia, no 80, 2018, p. 171-181. Maracaibo, Venezuela. 
PROGRAMA MERCOSUL SOCIAL E SOLIDÁRIO. Estatuto da Cidadania do MERCOSUL e Plano Estratégico de Ação Social: Conquistas e Desafios pendentes. Novembro, 2016. Disponível em: <http://www.mercosursocialsolidario.org/wp/wpcontent/uploads/2017/05/PEAS-portugues-26MayoB1.pdf >. Acesso em: 15 jul. 2018.

SCOTTI, Luciana B. El derecho de la integración en el Mercosur. In: NEGRO, Sandra C. Derecho de la Integración. Buenos Aires: Editora B de f, 2018.

SILVA, Wanise Cabral. AMARAL, Nemo do Andrade. A imigração na Europa: a ação política da União Europeia para as migrações extracomunitárias. In: Sequência (Florianópolis), Florianópolis, n. 66, p. 235-259, julho 2013. Disponível em: <http://www.scielo.br/pdf/seq/n66/10.pdf>. Acesso em: 08 jul. 2018.

Tratado de Assunção para a Constituição de um Mercado Comum. 26 março 1991. Disponível em: <http://www.mercosur.int/innovaportal/file/719/1/CMC_1991_TRATADO_ES_Asuncion.pdf >. Acesso em: 10 jul. 2018.

UE sela pacto para criação de "centros de triagem" de imigrantes. In: El País, 29 junho 2018. Disponível em: <https://brasil.elpais.com/brasil/2018/06/28/internacional/1530211799_743899.html>. Acesso em: 21 jul. 2018.

VIEIRA, Luciane Klein. La hipervulnerabilidad del consumidor transfronterizo y la función material del Derecho Internacional Privado. Buenos Aires: La Ley, 2017.

WERMUTH, Maiquel Ângelo Dezordi. A produção da vida nua no patamar de (in)distinção entre Direito e Violência: a gramática dos imigrantes como "sujeitos de risco" e a necessidade de arrostar a mixofobia por meio da profanação em busca da comunidade que vem. 2014. 276 f. Tese (Doutorado em Direito). Programa de Pós Graduação em Direito, Universidade do Vale do Rio dos Sinos, São Leopoldo. 2014. 